\title{
A Conceptual Study on Pedagogical Formation Students: Gender ${ }^{\mathrm{i}}$
}

\author{
Sinem Tarhan", Fatma Ünal, Eda Çürükvelioğlu Köksal \\ Faculty of Education, Bartın University, Turkey
}

Copyright $\bigcirc 2017$ by authors, all rights reserved. Authors agree that this article remains permanently open access under the terms of the Creative Commons Attribution License 4.0 International License

\begin{abstract}
While the biological differences accepted by the individuals themselves are seen as sex differences, at the point of socializing the society culture, the differences in the ways of behavior, emotion, and role which are taught are seen as 'acceptable' according to the sex are seen as gender role differences. This study aimed to investigate the pedagogical formation students' attributions towards gender concept and to determine the definitions oriented to the 'gender' regarding sex. The study was designed in the frame of qualitative research. The study group consisted of 156 participants. As data collection instruments, semi-structured interview form was used and the data evaluated with content analysis. Findings indicated that for both male and female participants the themes like 'work/mother/father', 'traditions' and 'male superiority' came into prominence. For female participants, it went in turn as 'stress/violence' and 'insignificance' themes; for male participants it followed as 'discrimination', 'inequality', 'stress/violence' and 'insignificance' themes.
\end{abstract}

Keywords Gender Equality, Sex Discrimination, University Student

\section{Introduction}

Scientists, for hundreds of years, have been made researches on classifications based on some physical, psychological, cultural, cognitive etc. features in order to understand and know humans. Similar classifications were also occurred in culture over time and it caused the groups governing and being governed by political, social and religious norms to emerge. Either scientifically or culturally, the knowledge determined by these classifications affected the manners and behavior of one person/group towards another person/group. Sex is a significant classification in both in science and culture. The stereotypes (Kağıtçıbaşı, 2013) that stated as a summary of the information obtained about certain groups are also determiner on sex.

The development level of a society is measured with the rights given equally to males and females. Even if the constitution of the Republic of Turkey shows its commitment with signing several agreements, contracts and commitments such as some national regulations like the constitution of elementary school numbered 1793, Civil Code; and international ones like the Contract of avoiding Every Discrimination Against Women (CEDAW, 1985), Beijing Declaration and Action Plan (1995), the Contract of Children Rights (1995), International Labor Organization (ILO), Contracts and Century Development Goals (2000), European Social Charter; unfortunately it still cannot reach the desired level on the equality between men and women.

According to Alisbah Tuskan (2012), the main reason that women who are half of the population cannot gain a modern statue based on equal rights is the way of perceiving women in society. How women and men perceived, which social role, duty and rights they have in society are shaped in the frame of gender stereotypes. As for stereotypes are the products of patriarchal traditions (Bingöl, 2014). Depending on gender, the morals roles and models appraised for men and women are hierarchically discriminators with the reason of accepting men 'superior and top' and women an 'other' (Bingöl, 2014). The stereotypes of gender determine the men's and women's attendance way, rate and visibility to social life in a society (Öngen and Aytaç, 2013). On a patriarchal base, the roles expected from women are giving birth and to raise a child, doing housework like cooking, washing dishes, cleaning, being patient and obedient, and making sacrifices for her husband and children. On the other hand, the roles expected from men are bearing material responsibility of the family, being a protector for his wife and children. While social and political life is under the men's control, the women's area of responsibility is determined as their home and family. The fact that the existence area of women is restricted as home is one of the biggest obstacles in front of the periods of taking place in social life, earning money, 
having healthcare delivery, acquiring a profession and taking education. According to the statistics of TÜIK (Turkish Statistical Institute) in 2015, among each illiterate 10 people, 8 are women in our country. When the educational statistics are analyzed, it is clear that downward from primary school to higher education, the rate of taking education is decreasing especially among women (KSGM, 2017). The women employment between the ages of 15-64 is on a very low level compared to men employment (Tokol, 2011). The educated women are led to choosing traditional groups of profession (like teacher, doctor, nurse) (Saraç, 2013; Şalvarlı Türeli and Dolmacı, 2013), whereas uneducated women work for the jobs requiring no qualification and for agriculture (Karabıyık, 2012). Giving priority to housework and care for her husband and children is an obstacle for educated women in advancing in her career, continuing her education, bearing her work life, and improving herself individually. However, uneducated women mostly work for temporary, daily, part-time family works with lower prices and in bad conditions, and they face the discrimination in employment, payment and promotions (KSGM, 2008). The women attendance to politics and decision-making procedures is also restricted. In local elections of 2009 in our country, the rate of mayoress was $0,9 \%$, this rate in 2014 elections increased to $2,9 \%$. While the headwoman rate in local elections of 2009 was $2,3 \%$, in 2014 elections this rate increased to $2 \%$ (TÜIKK, 2016).

The gender discrimination is accepted as one of the biggest obstacles for social and economic development, without eliminating gender inequality, it is impossible that social and economic improvement will come true (TCÇGR, 2013). There are various studies taking gender issue from different aspects. Some of these are gender and social roles (Alisbah Tuskan), legal regulations (Gündüz Hoşgör, 2008; Konan, 2011), the manners of university students towards gender (Öngen and Aytaç, 2013; Vefikuluçay, Zeyneloğlu, Eroğlu and Taşkın, 2007; Vefikuluçay, Yılmaz, Zeyneloğlu, Kocaöz, Kısa, Taşkın and Eroğlu, 2009), gender and education (Gümüşoğlu, 2008; Seçgin and Kurnaz, 2015; Çabuk Kaya, 2013), choosing profession and work life (Parlaktuna, 2010; Şalvarcı Türeli and Dolmac1, 2013; Nergiz and Yemen, 2013). These studies were made on the fields affected by gender stereotypes but in literature, there was no study analyzing what gender was and how it was understood. In this study, it was aimed to examine the meaning that pedagogical formation students ascribed to gender and to determine the definitions of 'gender' according to sex.

\section{Method}

\section{Research Design}

This study was conducted in qualitative research design.
The reason of choosing qualitative research design in the study is the desire for examining gender concept based on the meaning and understanding. According to Van Maanen $(1979,520)$, a qualitative research is an umbrella term and it contains defining, solving, commenting, and the techniques reached to the terms about meaning (Merriam, 2013, 13). Qualitative researches are about how the meaning is built, how people give meaning to their life and world. The main purpose of qualitative research is to release these meanings and comment on them (Merriam, 2013, 24). In this context, in the present study, how university students define and give meaning to gender concept is tried to be released and commented. Moreover, it is tried to determine how gender is affected from sexes of individuals.

\section{Study Group}

On deciding the working group of the study, easy access and volunteering to work were the bases and convenience sampling method was applied. Convenience sampling is defined as the easy accessible exemplification made on the individuals who want to be involved in the research voluntarily (Yıldırım and Şimşek, 2016). It was decided that the participants of the study would be gathered from the trainees enrolled in the certificate program of pedagogical formation education opened in 2016-2017 academic year of Bartın University. The main reason of this was the adult trainees applied for this program were graduated or as final year undergraduate students from different cities and cultures. This difference and variety was taken as an advantage for examining the meanings attributed to the concepts like gender. The distribution of the trainees who attended the study is shown in Table 1 according to their faculties and sexes.

Table 1. Frequency distribution of participants according to their faculties and sexes

\begin{tabular}{|c|c|c|c|}
\hline Name of the Faculty & Sex & $f$ & Total \\
\hline \multirow{2}{*}{ Physical Training and Sports } & Female & 9 & \multirow{2}{*}{30} \\
\hline & Male & 21 & \\
\hline \multirow{2}{*}{ Literature } & Female & 25 & \multirow{2}{*}{48} \\
\hline & Male & 23 & \\
\hline \multirow{2}{*}{ Science } & Female & 11 & \multirow{2}{*}{23} \\
\hline & Male & 12 & \\
\hline \multirow{2}{*}{$\begin{array}{l}\text { Economics Administrative and } \\
\text { Social Sciences }\end{array}$} & Female & 12 & \multirow{2}{*}{20} \\
\hline & Male & 8 & \\
\hline \multirow{2}{*}{ Islamic Science } & Female & 5 & \multirow{2}{*}{15} \\
\hline & Male & 10 & \\
\hline \multirow{2}{*}{ Health Sciences } & Female & 17 & \multirow{2}{*}{20} \\
\hline & Male & 3 & \\
\hline \multirow{2}{*}{$\begin{array}{l}\text { Female } \\
\text { Male }\end{array}$} & Total & 79 & \multirow{2}{*}{156} \\
\hline & Total & 77 & \\
\hline
\end{tabular}

According to Table 1, of 156 trainees participated to the study, 79 were female, 77 were male. All participants are in final year or graduated 30 participants from Physical Training and Sports, 48 from Literature, 23 from Science, 20 from Economics Administrative and Social Sciences, 15 
from Islamic Sciences, and 20 from Health Sciences Faculties.

\section{Data Collection Instruments and Procedure}

In data collecting process, semi-structured interview form with one question was used. Semi-structures interviews combine both fixed alternative answer and detailed explanation on related field. At the same time, semi-structured interviews have advantages like expressing oneself to the interviewee and eliciting in detail if necessary (Büyüköztürk et.al, 2009, 163). At the first chapter of the interview form, the sex and faculty information of the participants were asked and at the second chapter, only one question 'What do you understand from gender?' was asked. In order to provide participants could express themselves openly, no variable information was included except for sex and faculty. In case the participants might be affected from any person or situation, the researchers chose to collect data with a form they could express the ideas in writing instead of a face-to-face meeting. The researchers carried out the practice.

\section{The Analysis of the Data}

In the present study, the data collected about the gender concept were evaluated with content analysis method. The researchers tried to define the words/sentences and to reveal the possible hidden meanings in them with content analysis. In content analysis, the data were conceptualized at first, then according to the revealed concepts, they were organized reasonably, and finally the themes explaining the data were determined (Yıldırım and Şimşek, 2016, 162). The qualitative research data were analyzed in four steps. These were coding the data, finding the themes, organizing the codes and themes, defining and commenting the facts (Yıldırım, Şimşek, 2016, 163). In the study, the researchers at first accepted the given answer as a whole and tried to find the meanings about the gender concept. The step of coding these data was carried completely on coding given answers and a code list was created. The similarities and the differences emerged in the code list were figured out and according to this the themes containing interrelated codes were stated. In order to analyze the accord of the themes emerged and to check whether the data were organized effectively, expert opinion was asked at this step. Researchers separately studied the codes of interview answers and compared them to ensure the reliability in analyzing the data.. For the reliability of the study, the coding decided with one accord among the researchers were taken into account and it was required that two different expert would evaluate the coding separately. It was clear that the coding made by the researchers was consistent with the literature. As for ensuring the validity of the study, no sampling was taken from the analyzed sentences but they were all examined. The female participants were coded as F1, F2.. etc. whereas the male participants were coded as M1, M2.. etc. and also direct quotations from their answers were used. In the analysis there was no difference according to the faculty factor, therefore the data were written considering only the sex factor. Moreover, it could be seen that the female participants had written more sentences while answering 'What do you understand from gender?' whereas the male participants had answered the same question with a couple of words or with just one sentence.

\section{Findings}

In this section, the findings on the given answers of the participants about gender concept were stated.

\section{Findings on Gender Concept}

The results of given answers of the participants to 'What do you understand from gender?' question were shown in Table 2 according to the themes.

Table 2. Distribution of the themes on gender concept

\begin{tabular}{cc}
\hline Name of the Theme & Frequency \\
\hline Work/mother/father & 138 \\
Traditions & 112 \\
Male superiority & 88 \\
Stress/violence & 53 \\
Discrimination & 52 \\
Insignificance & 42 \\
Inequality & 40 \\
Sexuality/chastity & 17 \\
Weakness & 13 \\
\hline
\end{tabular}

As it can be seen in Table 2, the most used theme in defining and understanding the gender concept was work/mother/father with the rate of 138 . The themes followed in turn as tradition (112), male superiority (88), stress/violence (53), discrimination (52), insignificance (42), inequality (40), sexuality/chastity (17) and weakness (13).

\section{Findings on Gender Concept According to Sex}

According to the sexes of the participants, the results of the answers given to 'What do you understand from gender?' question were shown in Table 3 according to the themes. 
Table 3. Distribution of the Themes on Gender Concept According to Sex

\begin{tabular}{|c|c|c|c|}
\hline Sex & Name of the Theme & Frequency & Example Sentence \\
\hline \multirow{9}{*}{ Female } & Work/mother/father & 83 & $\begin{array}{l}\text { - "Housework is considered as the duty of women only." (F21) } \\
\text { - "Women are mothers, do housework; men are fathers, work outside to bring home } \\
\text { the bacon." (F8) }\end{array}$ \\
\hline & Traditions & 68 & $\begin{array}{l}\text { - "The social roles of men and women were understood differently due to their } \\
\text { sexes. We are a patriarchal society. Men have more active roles whereas women are } \\
\text { passive and restricted." (F7) } \\
\text { - "Whatever men do is alright, for women no way." (F17) } \\
\text { - "Womanhood is a desperation taught. Women are petticoats. Nevertheless, they } \\
\text { are irreplaceable for life and men." (F28) }\end{array}$ \\
\hline & Male superiority & 48 & $\begin{array}{l}\text { - "Men are born lucky. In our country, there is a silly thought like men are superior } \\
\text { to women." (F2) } \\
\text { - "Women are always weak, men are always strong! Woman is a possession, man is } \\
\text { a possessor." (F49) }\end{array}$ \\
\hline & Stress/violence & 40 & $\begin{array}{l}\text { - "Women are stressed in every aspect." (F9) } \\
\text { - "Beaten, murdered, harassed, raped sex. That is woman." (F64) }\end{array}$ \\
\hline & Insignificance & 34 & $\begin{array}{l}\text { - "Being a woman is hard. Women are always looked down and alienated in life. } \\
\text { They stay in the background." (F8) } \\
\text { - "Women are always at the oppressed side, unfortunately." (F61) }\end{array}$ \\
\hline & Discrimination & 25 & $\begin{array}{l}\text { - "Girls are not allowed to take education. Boys are supported after whatever they } \\
\text { do." (F33) } \\
\text { - "Women are restrained in many professions because they are for men." (F29) }\end{array}$ \\
\hline & Inequality & 23 & $\begin{array}{l}\text { - "Women were left in the background as a sex." (F6) } \\
\text { - "In society, men and women are not equal unfortunately." (F44) }\end{array}$ \\
\hline & Sexuality/chastity & 17 & $\begin{array}{l}\text { - "They both consider women as chastity and high-honored and they put women } \\
\text { aside and scorn."(F11) } \\
\text { - "Women are considered just for chastity and sexual object and men are the only } \\
\text { sex in our society." (F22) }\end{array}$ \\
\hline & Weakness & 13 & $\begin{array}{l}\text { - "When it comes to women, delicateness, weakness, fragility comes to mind. They } \\
\text { are always seen as indigent for protection." (F14) } \\
\text { - "It is considered that women are always indigent for protection and they cannot do } \\
\text { lots of things due to their weakness." (F23) }\end{array}$ \\
\hline \multirow{7}{*}{ Male } & Work/mother/father & 55 & $\begin{array}{l}\text { - "Women raise children at home, clean and cook. Men are fathers; they rule the } \\
\text { roost and earn money." (M42) } \\
\text { - "Be the woman of your house and mother of your children. I am against working } \\
\text { women." (M54) }\end{array}$ \\
\hline & Traditions & 44 & $\begin{array}{l}\text { - "Morals looking down women force them to marry the unwanted ones. They } \\
\text { become brides at a child age. Without breaking down these taboos, women stay in } \\
\text { the background." (M37) } \\
\text { - "In our society, the sex of an individual affects his/her statute and importance. } \\
\text { According to our traditions, women are chastity. Women cannot even go outside as } \\
\text { they wish." (M47) }\end{array}$ \\
\hline & Male superiority & 40 & $\begin{array}{l}\text { - "We are a patriarchal society. So there is a man-governing life." (M13) } \\
\text { - "Being a headman or manager is suitable for men. Men are seen as superior and } \\
\text { governor." (M34) }\end{array}$ \\
\hline & Discrimination & 27 & $\begin{array}{l}\text { - "Women cannot work as they wish. They have recently seen on work life in } \\
\text { society." (M23) } \\
\text { - "Women always face with discrimination in society. The role of women is hard. I } \\
\text { do not wish to be a woman." (M28) } \\
\text { - "Women do not take education or work but raise children at home and serve for } \\
\text { husband." (M55) }\end{array}$ \\
\hline & Inequality & 17 & $\begin{array}{l}\text { - "Men and women's not being able to live under the same conditions in the same } \\
\text { society." (M5) } \\
\text { - "Except for physically, men and women should be equal. Unfortunately, this } \\
\text { equality cannot be performed well." (M68) }\end{array}$ \\
\hline & Stress/violence & 13 & $\begin{array}{l}\text { - "We have a society that it restricts and prejudges women." (M15) } \\
\text { - "I am so sick of hearing women murders every day." (M40) }\end{array}$ \\
\hline & Insignificance & 8 & $\begin{array}{l}\text { - "Women have no significance. Men are important in family." (M10) } \\
\text { - "Due to her gender, women are always placed at the oppressed side." (M43) }\end{array}$ \\
\hline
\end{tabular}


In Table 3, on defining and understanding gender concept for both male and female participants, it can be seen that themes like 'work/mother/father', 'traditions' and 'male superiority' come into prominence. For female participants, the themes follow in turn 'stress/violence', 'insignificance', 'discrimination', 'inequality', 'sexuality/chastity' and weakness whereas for male participants, the themes follow in turn 'discrimination', 'inequality', 'stress/violence' and 'insignificance'.

\section{Results, Conclusions and Recommendations}

In the present study, the definitions of pedagogical formation students for gender concept were examined. Gender is the roles and responsibilities assigned to men and women by society. Although men also face some restrictions and difficulties, the victims of gender inequality are mostly women. This issue is understood in that way in society as well. That is why, it was determined in the study male and female teacher candidates defined gender concept more on problems of women. It can be seen in the study that male students wrote less sentences on discussing gender concept, and they stated mostly the aspects women suffer from. From the sentences of male participants, it is clear that they are aware of unequal and discriminative manners towards women yet they wrote on the supportive stereotypes and recreate them.

On defining gender concept, in terms of both male and female participants, the themes of 'work/mother/father' and 'male superiority' come into prominence. 'Work' implies housework like cleaning, cooking, washing the dishes etc. It was determined that, besides being a mother, housework were considered as the main duty of women and the living area of them was limited with the house. On the other hand, the main duty of men was stated as being a father and working outside to earn money. These facts are consistent with the literature. According to Bora (2011), in our culture, womanhood is defined and recreated with 'house', independently from the factors like age, education and social class. Similarly, Bingöl (2014) also stated that in Turkish society, the qualifications equal to the concept of 'womanhood' are more about femininity than the features of an equal, independent and free individual thus the concepts for women primarily like wife, mother or a member of the family are suitable. Remarking the perspective towards women is contradictory, Alisbah Tuskan (2012) expressed that as well as the motherhood and fertility of women are important for the continuation of generation, women have been despised and exploited throughout history. This contradictory situation, called as emotionally contradictory sexism by Glick and Fiske (1996), has two dimensions, which are hostile sexism and protective sexism. Hostile sexism contains the situations in which some negative attitudes are presented openly, as for the dimension of protective sexism contains positive manners and attitudes to women. In this study, it was found that male teacher candidates used statements containing emotionally contradictory sexism.

The results of a research conducted with 200 men by Sancar (2009) are significant both from the point that it represents the gender perception of the men from different cultural and social backgrounds (religious, conservative and country based; modern, urbanite and middle-class) are similar and from the point that the results state the components of the ideological structure emerged. One of the most significant facts of the research is the thought that sexual inequality is about congenital biological differences and unalterable. Accordingly, the thought that human nature obliges sexual-social differences is a thought that feeds 'male dominance' and is supported by different segments of society. Thereby, male violence and female obedience turn into a need of biological sex. According to Tolan (1991), women becoming socialized under the pressure of their father and brothers in traditional families maintain this process in the relations with their husband when they married. While this relation of dependency is infused into girls since their childhood, 'independent' boys are raised as being able to take all the responsibility and economical duty of the house in the future.

Because of the viewpoint of women whose sexuality may attract men and breach the social peace, a tight control is conducted on women over the concepts such as chastity and virginity (Mernissi, 1987; et.al Kalav, 2012). The same thought is carried on with the statement of a male participant like 'if women are not covered and taken under control, they will breach the social peace' in the research of Tahincioğlu (2011), Previously, the chastity concept surrounded by the words like possession, soil and kinship, turns into the understanding filled with the concepts like nationality and modernism (Kalav, 2012). In Turkey, chastity means honesty for men, sexuality for women and the chastity concept is defined over female body. The chastity of a woman is seen as the chastity of the society and her family. That is why the one who should control the sexuality in family is the woman. Although in daily life the sexuality of a woman is simply ignored, the sexuality of a heterosexual man is exaggerated (Mutluer, 2007; Alisbah Tuskan, 2012). Chastity is stemmed from the customs and traditions related to sexual behavior and it requires sexual avoidance as a rule (Bilgili and Vural, 2011). This avoidance is a matter of women because of the sexual stereotypes and it brings along the discrimination towards women in bilateral relationships. Although it is approved and even encouraged men have lovers and have sexual intercourse before marriage since their childhood, for women even making a friendship with men poses a problem (Saraç, 2013). On behalf of saving chastity, women's taking education and stepping into work life are restricted or strictly controlled. The little girls who are not educated with the reasons like morals, chastity are forced to marry in very early ages, cannot get in the society as 
productive and independent citizens and the possibility of being beaten is increasing (Alisbah Tuskan, 2012). In this research, female participants combined the chastity concept and gender. Besides the difficulties they face as women in society, they also take attention to men's contradictory perspective towards women (e.g. protecting, giving confidence but throwing them background out of focus).

Another concept that male and female pedagogical formation students associated with gender is the concept of stress and violence. Violence against women is defined as all types of sexual violence which may or do cause women to suffer from it psychologically, physically or sexually including arbitrary subjection from freedom and threatening dominantly in domestic or public life (UN, 1993). In several countries, violence maintains as elements of traditional culture and as primitive practices against women and children. The researches made in the different regions of the world express that violence against women is strictly bound to the description of gender roles. Men hiding behind gender stereotypes commit violence by creating stress and associating manhood with strength, manhood pride and prevalence (Ünal, 2005). At the heart of male violence against women, demand of men over women underlies (Arat, 1995). When it comes to violence, the first thing coming to mind is physical violence so women mostly cannot even recognize they face with other types of violence like verbal, psychological, economical, sexual or at least one of them. According to Belek (2013), women's acceptance of taken under control is about the fact that she accepts and does not find odd the discrimination created by this dominance. Therefore, by giving individuals the education on the topics of violence (what violence is, what its types are, how to control anger, how to protect from violence, etc.) public awareness may be raised. Especially young women's realization of violence and assertion may cause both men to control themselves and women to protect themselves from the possible violence in marriage. Understanding and defining the domestic violence usually shape over cultural values of society and individual. For this reason, when using violence occurs for a goal that society adopts and approves, it is hard to understand and define that behavior as violence (Levesque, 2001). Unfortunately, also in our country, violence against women is legitimated with cultural concepts like chastity and morals, and it is tried to be shown as right in terms of men. However, after once violence starts to be performed and taken normally, there is a possibility for women to face with violence even during their pregnancy that is a special and caring period (Ayranc1, Günay and Ünlüoğlu, 2002). Some of the reasons of violence are financial difficulties, lack of education, wrong learning, social and legal rules' being not enough deterrent, human and human rights' not being precious, mental disorders. Violence tried to be covered up with cultural values and seen as only against women and children spread through every area and group (traffic, entertainment center, shopping mall). Accordingly, educators and policy makers should accept violence as a violation of human rights and overemphasize it.

The other concept that participants associate with gender is discrimination. The discrimination against women is defined by CEDAW (1979) as 'any kind of discrimination, deprivation and restriction made according to sex, abolishing and ignoring the utilization, usage, and understanding of fundamental rights and freedoms in political, economic, social, cultural and civil fields on the basis of the equality between men and women without considering the marital status of women'. Discrimination brings with inequality. Unequal practices prevent women from living, taking education, choosing profession, having economical income, taking a share from heritage, having a voice in society and house and using public area freely. Gender equality is usually thought as physical equality and the perspective defending the inequality of men and women is supported. When as, on the topic of rights, gender equality shows the equality of men and women before laws and society. This equality is one of the key conditions in order to be a democratic and developed society. According to Saraç (2013), in order to ensure sex equality, equal rights should be provided to understand and lead their capacities freely without concerning their sexes. Likewise, in order to create gender equality, men and women should accept each other at first as human and then respect. That is why, education is important. Taking education and working change the perspectives of people. Aktaş (2013) claims that education of women/girls ensure them to be determiners in their decision mechanism about life. Moreover, educating girls helps them to invest in economic, social and cultural life areas especially in the future and at the same time, it contributes to their personal improvement, gaining trust, knowing social life areas and becoming self-supporting by joining in work life.

In this study, another concept defined on behalf of women and thought its being about gender is 'insignificance/not valued'. In these statements as well, the traces of emotionally contradictory sexism can be seen. Value may be examined in two dimensions. The first is the value as a human. In our culture, women who tried to be aggrandized with the saying 'heaven is under the feet of mothers' actually is not of value. As it is stated in some proverbs like 'long hair, short mind', 'ball and chain', 'do not get in men's work with the dough on your hand', women are on the second class. In fact, in our society, the report of the unborn being male, birth of a boy, existence a boy in a family are still important. This situation unavoidably causes the girls of the family to feel like they are insignificant. The second dimension of value is economic strength. Bhasin (2003) expresses that compared to men, women have less rights and less resource. The labor of women at housework, at agriculture as family worker, at the care and peace of family members are not considered significant. The financial payment of this labor is not given, too. Because of the gender stereotypes, the 
income of women who cannot take education, cannot get a job, have not got a right for possession, cannot have financial income or forced to work as unskilled workers with a low salary and no social security is not considered precious, either or it is not called as a 'breadwinning'.

Another word that female participants used while describing gender concept is weakness. Children start to realize their sex at the ages between 4 and 5 whether they are boys or girls. The toys chosen for children, the games they are allowed to play, how to speak and which words to use, which emotions they must feel are shaped by gender stereotypes. It is supported for girls to be quiet, helpful, tend to housework, skillful, well-kept and strong in social relations whereas for boys to be confident, strong, ambitious, tend to technical works (Dökmen, 2004; Çelik, 2008). On the other hand, the message that she can be strong if she is one's wife or daughter is given. The personalities and behavior patterns are shaped in this way. Sensitive, emphatic, sharing and egalitarian manners of women are considered as sensuality and weakness. In other words, the values taught girls are held against them as adults. Especially in work life, decisive, ambitious and entrepreneurial women are blamed for drifting away womanhood. By this way, the voice women have in social life, politics and work life in short men's world is prevented.

Gender is an issue concerning men at the same time. Simone de Beauvoir underlines that manhood is a potency founded by talking about not their own sex but the sex qualifications of the others and this potency leaves the self-existing position aside questioning (Sancar et.al, 2009). In this study as well, male participants handle the gender concept as if it is the problem of only women and they do not state the hardships they face. Maybe the topic should be focused on is whether men are aware of the fact that gender stereotypes restrict themselves too because awareness on a topic ensures endeavor for the solution of the issue as well. Women's realization of the gender inequalities they faced and the stereotypes creating these inequalities, improvement of the sensibility to the problems of women may be an important step for solving the problems. This is because with the result of a group of women's being insensible to the discrimination or violence that does not exist in their lives and another group of women's acceptance the inequality and unfair behavior towards themselves, the stereotypes of women roles existing for years stay forever. When it comes to gender equality, it always opens a topic of raising children of women and saying 'men are also raised by women' women are blamed for recreating the inequality. The subjects of how to raise girls and boys, how to teach girls their rights and boys their limits, violence and jealousy not meaning love exhibiting, sharing resources fairly and in the conditions of today boys having no guarantee, it is important for men and women get awareness. Coward (1995) states that men feel restricted by the male understandings advising no crying, no being delicate or polite, and no raising children so it should be researched what women contribute to this male understanding as mothers or lovers. As well as understanding how women live their humiliation, it is also important to understand how men create and maintain male potency, how new generation describe themselves, how men have an attitude in the changing society and roles (Zeybekoğlu, 2009). In other words, men should also question the meaning and responsibilities of being a man. Moreover, men should review themselves together with how a livable world is possible for their mothers, wives, lovers, girlfriends and daughters. Although we are at the age of information and communication, still by hiding behind traditions, customs, religion and social rules, one sex creating stress on the other and restricting their usage of basic rights and freedoms are inacceptable so it is not possible for society to be happy and peaceful. To ensure gender equality, a cognitive change and transformation are compulsory. The cultural change creating equality will be possible just in this way.

In accordance with findings of this study, these may be suggested:

- Starting from pre-school, at educational institutions, creating and improving equality stereotypes,

- In all higher education institutions, opening courses and programs on gender equality to create awareness,

- In written and visual media, blocking the sexist messages in commercials,

- In the curriculum practiced at common schools, emphasizing the gender equality.

\section{REFERENCES}

[1] Aktaş, G. (2013). Feminist söylemler bağlaminda kadin kimliği: Erkek egemen bir toplumda kadin olmak. Hacettepe Üniversitesi Edebiyat Fakültesi Dergisi, 30 (19), 53-72.

[2] Alisbah Tuskan, A. (2012). Toplumsal Cinsiyet Toplumda Kadına Biçilen Roller ve Çözümleri. tbbdergisi.barobirlik.org.tr/m2012-99-1179.

[3] Ayrancı Ü, Günay Y, Ünlüoğlu İ. (2002). Hamilelikte aile içi şiddet: Birinci basamak sağlık kurumuna başvuran kadınlar arasında bir araştırma. Anadolu Psikiyatri Dergisi, $3,75-87$.

[4] Ataöv, T. (1996). Çatışmaların Kaynağı Olarak Ayrımcılık, A.Ü.S.B.F. İnsan Hakları Merkezi Yayınları, Zirve Ofset, Ankara.

[5] Belek, U. (2013). Toplumsal Cinsiyet Algısının Statik Duruşu. Toplumsal Cinsiyet ve Yansımaları (içinde), Atılım Üniversitesi Yayınları, Ankara.

[6] Bhasin, K. (2003). Toplumsal Cinsiyet Bize Yüklenen Roller. Kadav Yayınları, Çev: Ayşe Coşkun, İstanbul. 
[7] Bilgili, N. ve Vural, G. (2011). Kadına yönelik şiddetin en ağır biçimi: Namus cinayetleri. Anadolu Hemşirelik ve Sağlık Bilimleri Dergisi, 14(1), 66-72.

[8] Bingöl, O. (2014). Toplumsal cinsiyet olgusu ve Türkiye'de kadınlık. KMÜ Sosyal ve Ekonomik Araştırmalar Dergisi 16 (Özel Sayı I), 108-114.

[9] Büyüköztürk, Ş., Kılıç Çakmak, E., Akgün, Ö.E., Karadeniz, Ş. ve Demirel, F. (2009). Bilimsel Araştırma Yöntemleri (4. Bask1). Ankara: Pegem Akademi Yayınları.

[10] CEDAW. 1979. Kadınlara Karşı Her Türlü Ayrımcılığın Önlenmesi Uluslararası Sözleşmesi. https://www.unicef.org/turkey/pdf/_gi18.pdf

[11] Coward, Rosalind. 1995, Kadınlar erkeklere neden teslim olurlar?. İstanbul: Ayrınt1 Yayınları.

[12] Çabuk Kaya, N. (2013). Türkiye' de Toplumsal Cinsiyet Eşitliği ve Eğitim http://kizlarinegitimi.meb.gov.tr/KEP-I/files/img/toplum_c insiyet_ve_egitim.pdf

[13] Çaycı, M.Ş. 2014. Toplumsal cinsiyet bağlamında kadın; Cinsiyet ayrımcıliğının kadın ăgzı türkülerde işlenişi. (Yayınlanmamış yükse lisans tezi). Haliç Üniversitesi Sosyal Bilimler Enstitüsü.

[14] Çelik, Ö. (2008). Ataerkil sistem bağlaminda toplumsal cinsiyet ve cinsiyet rollerinin benimsenmesi.

Yayınlanmamış yüksek lisan tezi. Gazi üniversitesi.

[15] Çer, E. \& Şahin, E. 2016. Türkçenin sözvarlığını yanısıtan atasözleri ve deyimlerde toplumsal cinsiyet. International Periodical for the Languages, Literature and History of Turkish or Turkic, 11(9), 175-192. DOI Number: http://dx.doi.org/10.7827/TurkishStudies.9632

[16] Dökmen, Z. Y. (2004). Toplumsal Cinsiyet: Sosyal Psikolojik Açılklamalar. İstanbul: Sistem.

[17] Glick, P., \& Fiske, S. T. (1996). The ambivalent sexism inventory: Differentiating hostile and benevolent sexism, Journal of Personality and Social Psychology, 70(3), s. 491-512.

[18] Gümüşoğlu, F., Ders kitaplarında toplumsal cinsiyet, Toplum ve Demokrasi, 2 (4), 39-50.

[19] Gündüz Hoşgör, A. (2008). Kadın vatandaşlik haklarındaki en temel sorun: "Nüfus cüzdanım yok ki!", Toplum ve Demokrasi, 2 (4), 27-38.

[20] Kalav, A. (2012). Namus ve toplumsal cinsiyet. Mediterranean Journal of Humanities, 2(2), 151-163.

[21] Karabıyık,İ. (2012). Türkiye'de çalışma hayatında kadın istihdam1. Marmara Üniversitesi İ̈BF Dergisi, 32(1), 231-260

[22] KSGM 2017. Türkiye'de Kadın. T.C. Aile ve Sosyal Politikalar Bakanlığı Kadının Statüsü Genel Müdürlüğü. http://kadininstatusu.aile.gov.tr/uygulamalar/turkiyede-kad in

[23] Konan, B. (2011). Türk Kadınının Siyasi Hakları Kazanma Süreci. AUHFD, 60 (1), 157-174

[24] Levesque J. R. (2001). Culture and Family Violence:
Fostering Change Through Human Rights Law.

[25] Merriam, S.B. (2013). Nitel Araştırma Desen ve Uygulama Için Bir Rehber. (S. Turan, Çev.). Ankara: Nobel Yayınları.

[26] Mutluer, N. (2007). Türkiye'de Cinsiyet Hallerinin Sınırları: "Namussallaştırma".

https://sosyolojiden.files.wordpress.com/.../tc3bcrkiyede-ci nsiyet-hallerinin-sc4b1nc4.

[27] Arat, N. (1995). Türkiye de Kadın Olmak. Say Yayılar1. İstanbul

[28] Negiz, N. ve Yemen, A. (2013). Kamu Örgütlerinde Kadın Yöneticiler: Yönetici ve Çalışan Açısından Yönetimde Kadın Sorunsalı. Süleyman Demirel Üniversitesi Fen Edebiyat Fakültesi Sosyal Bilimler Dergisi, Say1:24, s.195-214.

[29] Öngen \&Aytaç (2013). Üniversite öğrencilerinin toplumsal cinsiyet rollerine ilişkin tutumlari ve yaşam değerleri ilişkisi. Sosyoloji Konferanslar, 48, 1-18.

[30] Parlaktuna, İ. (2010). Türkiye'de cinsiyete dayali mesleki ayrımcılığın analizi. Ege Akademik Bakış, 10 (4),. 1217 1230.

[31] Sancar, S. (2009) Erkeklik: İmkânsız İktidar - Ailede, Piyasada ve Sokakta Erkekler, Metis Yayınları, İstanbul.

[32] Saraç, S. (2013). Toplumsal cinsiyet. Toplumsal cinsiyet ve yansımaları (içinde). Eds. Lerzan Gültekin, Gül Güneş, Ceylan Ertung, Aslı Şimşek. Atılım Üniversitesi Yayınları.

[33] Seçgin, F. ve Kurnaz, Ş. (2015). Sosyal bilgiler dersinde toplumsal cinsiyet etkinliklerinin öğrencilerin alg1 ve tutumlarına etkisi. Uluslararası Türk Ĕ̈itim Bilimleri Dergisi, 24-38.

[34] Şalvarcı Türeli, N. \& Dolmacı, N. (2013). İş yaşamında kadın çalışana yönelik ayrımcı bakış açısı ve mobbing üzerine ampirik bir çalışma. Ekonomi ve Yönetim Araştırmaları Dergisi, 2 (2).

[35] Tahincioğlu, N. (2011). Namusun Halleri. İstanbul: Positiga Yayinlar1.

[36] TCÇGR (2013) T.C. Kalkınma Bakanlığı 10. Kalkınma Planı, Toplumsal Cinsiyet Çalıșma Grubu Raporu. http://kasaum.ankara.edu.tr/files/2013/02/Toplumsal-Cinsi yet-

C3\%87al\%C4\%B1\%C5\%9Fma-Raporu-2013Bas\%C4\%B 1lacak-N\%C3\%BCsha.pdf

[37] Tokol, A. 2011. Günümüz Türkiye'sinde Giderek Ağırlaşan Sosyal Sorunlar ve Sosyal Politika Uygulamalarl. (Edt. M. Zencirkıran) Dünden Bugüne Türkiye'nin Toplumsal Yapıs1. s.545-559. Dora yayınevi, Bursa.

[38] TÜİK 2016. Türkiye İstatistik Kurumu. İstatistiklerle Kadın http://www.tuik.gov.tr/HbPrint.do?id=24643

[39] UN (1993). Declaration on the Elimination of Violence against Women.

http://www.un.org/documents/ga/res/48/a48r104.htm

[40] Ünal,G. (2005). Aile içi şiddet. Aile ve Toplum, 2(9), ISSN: 1303-0256. 
[41] Vefikuluçay,D., Zeyneloğlu, S. , Eroğlu, K. ve Taşkın, L. (2007). Kafkas üniversitesi son sınıf öğrencilerinin toplumsal cinsiyet rollerine ilişkin bakış açıları. Hacettepe Üniversitesi Hemşirelik Yüksekokulu Dergisi, 26-38.

[42] Vefikuluçay Yılmaz, D., Zeyneloğlu,S., Kocaöz, S., Kısa, S., Taşkın, L. Ve Eroğlu, K. (2009). Üniversite öğrencilerinin toplumsal cinsiyet rollerine ilişkin görüşleri.
Uluslararasi Insan Bilimleri Dergisi, 6 (1), 775- 792.

[43] Yıldırım, A. ve Şimșek, H. (2016). Sosyal Bilimlerde Nitel Araştırma Yöntemleri (10. Bask1). Ankara: Seçkin Kitabevi.

[44] Zeybekoğlu, Ö. (2009). Toplumsal cinsiyet bağlamında erkeklik olgusu. Yayınlanmamış yüksek lisans tezi, Akdeniz Üniversitesi.

\footnotetext{
${ }^{\mathrm{i}}$ This research was supported by Bartın University, Commission of Scientific Research Projects. (Project No: 2016 - SOS-A-013).
} 